\title{
A Study of Mental Health among Patients of Cancer
}

\author{
Dr. Arvind Dungrani *
}

\section{ABSTRACT:}

This study was conducted to investigate the difference in Mental Health among Patients of cancer. Total 60 samples of Male and Female cancer patients were taken from Sir. T. General Hospital from Bhavnagar City (Gujarat). Their Samples were also taken the data was collected with the help of 'Mental Health Inventory' Developed by Dr. A. K. Shreevastav and Dr. Jagdish (1982).The Original Hindi Inventory was translated in Gujarati and Standardized by Bhava Thummar (2009). The Data was used to obtain the Mental Health measurement of the subjects. The collected data was statistically analyzed with the help of ' $t$ ' test. The Results show that Mental Health for positive self Evaluation of the Male and Female Patients were not significant $(\mathrm{t}=0.17)$. The Mental Health for perception of Reality of the Male and Female Patients were not significant $(\mathrm{t}=1.34)$. The Mental Health for Integration of Personality of the Male and Female Patients were not significant $(t=1.74)$. The Mental Health for Autonomy of the Male and Female Patients were not significant $(t=0.66)$. The Metal Health for Group - oriented Attitude of the Male and Female Patients were not significant $(t=0.76)$. The Mental Health for Environmental Mastery of the Male and Female Patients were not significant $(t=0.20)$. The overall Mental Health of the Male and Female Patients were not significant $(t=1.25)$.

Keywords: Mental health, Cancer

\section{INTRODUCTION}

Motion is the aim of Society. Obstruction is not acceptable to it. Change is the essence element of it. Society has never remained motionless. Otherwise, its existence could not be there. But the speed and direction of change continuously change. Compared to earlier, time, today the society has become speedier. Change is taking place in each area; the said change is in both-physical area. In physical and non-physical state, the change in human psychology takes place so that mental balance is maintained. In changing time and developing always requires changing as per new situation. Change is life of all creatures.

The word 'Cancer' is derived from the word 'Cencurnm'. Its meaning is a 'Crab'. It is the most dangerous fatal disease. Cross of people in the world is suffering from the said disease (Patel1989). Physical disease affects mental state of an individual. When a fatal disease like Cancer is diagnosed, an individual is shattered only on hearing the name of disease.

* Assoc. Prof., Shamaldas Arts College, Maharaja Krushnakumarsinhji, Bhavnagar University, Bhavnagar. (Gujarat)

(C) 2014 A Dungrani; licensee IJIP. This is an Open Access Research distributed under the terms of the Creative Commons Attribution License (http://creativecommons.org/licenses/by/2.0), which permits unrestricted use, distribution, and reproduction in any Medium, provided the original work is properly cited. 
Mental restlessness starts on hearing the name of disease only. Everybody knows that there is treatment of all these diseases. Cure is possible on undergoing treatment. Despite that, he becomes engrossed in worries on hearing only the name. The form of worry many times takes the form of death worry also.

The issue of mental health is a burning issue of modern era. The human beings will have to cultivate the art of remaining healthy in modern era, if he intends to be happy and successful. A person who is mentally healthy can know himself. He can understand difference of true and false before carrying out any work and can ascertain future results. He has self confidence in himself and can see that there is some different place of his life in the world. Lack of self confidence is found in many individuals. He believes himself to be culprit for failure in any work.

William Osler has told that: "there is good or bad effect of mental health of individual on almost all illnesses" (Supra - Bhava Thummr- 2007). Successful treatment of disease like Cancer is based on what is in mind than on the characteristics in the body of patient. As per Freud: "Mental Health means to work with sense of positive ness and love" (Supra Patel-1989). This definition is specific and meaningful. Because, it is very tough to cultivate positive approach for happening of anything in life. Similarly, to work or get it done with love without creating any hesitation is an exclusive sign of healthy mind.

As per notification of international conference on Primary Health Treatment - Alma Aata USSR 1978, 'Health' means full physical, mental and social soundness. As per notification, mental health is individual capability of establishing harmony in social and physical atmosphere. As per opinion of Schreiberm (1951), mental health means strength to go further towards logical and objective aim of individual and successful use of capability and skill for the same. Such individual experiences security and attaining honors for being associated with something. He has knowledge that others like and love him. The individual has a feeling of attaining self respect, self-reliance and something and in addition, he learns to respect others, accept them and love them and live with others peacefully.

\section{METHODOLOGY}

\section{Hypothesis}

The following things of hypothesis have been formulated for the investigation, here, researcher builds a null hypothesis.

1) We do not find any difference in Positive Self Evaluation between Male and Female Patients of Cancer.

2) We do not find any difference in Perception of Reality between Male and Female Patients of Cancer.

3) We do not find any difference in Integration of Personality between Male and Female Patients of Cancer. 
4) We do not find any difference in Autonomy between Male and Female Patients of Cancer.

5) We do not find any difference in Group-Oriented Attitude between Male and Female Patients of Cancer.

6) We do not find any difference in Environmental Mastery between Male and Female Patients of Cancer.

7) We do not find any difference in Overall Mental Health between Male and Female Patients of Cancer.

\section{Sample}

60 Samples of Male and Female Patients of Cancer were randomly selected from Sir. T. General Hospital from Bhavnagar city (Gujarat). The care was taken that the socio-economic levels of all subjects remain almost the same.

\section{Tools}

For collecting the pertinent data, the following tools were used.

\section{(a) Personal Information Schedule}

The main purpose of this schedule is to collect certain pertinent data regarding the variables of the study, the various Information such as, type of Gender, Age, and level of education are collected through this schedule.

\section{(b) Mental Health Inventory}

The inventory was developed by Dr. A. K. Shreevastav and Dr. Jagdish (1982). to measure the Mental Health. Here is the information about the inventory. The original Hindi inventory was translated in Gujarati and standardized by Bhavna Thummar (2009). This inventory divided in six important areas of Mental Health in this inventory 56 questions. Each question has four options. It is sequence in this Always, Often, Some times and never to get target group has to choose any one option after data collection. It is analyzed and finds the solution.

Reliability

To decide reliability of this inventory by Dr. A. K. Shreevastav and Dr. Jagdish (1982). The reliability of Mental Health Inventory by Split-half method is $r=0.73(\mathrm{~N}=600)$.

The original Hindi inventory was translated into Gujarati by Bhavna Thummar (2009). They take 100 samples and decide the reliability of this inventory by Split-half method. To know the reliability of Dimensional Mental Health Inventory is $r=0.74$ 
Validity

To decide validity of this inventory by Dr. A. K. Shreevastav and Dr. Jagdish (1982). The validity of Mental Health Inventory by Construct validity is $r=0.57(\mathrm{~N}=600)$.

The original Hindi Inventory was translated into Gujarati by Bhavna Thmmar (2009). While translating this inventory help of language exports and interdisplinary subject was taken according to there content in the final Mental Health Inventory prepared not only this but we applied this test on 100 samples. The validity of Mental Health inventory by Construct validity is $r=0.68$. We found Correlation Significant.

\section{Procedure}

The Mental Health Inventory has six areas (1) Positive Self Evaluation (2) Perception of Reality (3) Integration of Personality (4) Autonomy (5) Group-Oriented Attitude (6) Environmental Mastery. To ask him to tick mark $(\checkmark)$ before the question if they agree with this Mental Health Inventory is to measure the four options, 'Always', 'Often' 'Sometimes' and 'Never'. 56 questions and Positive and Negative is Questions included in the Inventory. Positive is to be Scored 1, 2, 3 and 4. Negative is to be Scored as 4, 3, 2 and 1. The maximum is arrived at 224 and minimum score of 56 in this Inventory. It is interpreted that higher the area of value attained, the quantum of Mental Health is less and the lower the area of value attained, the quantum of Mental Health is more.

\section{RESULT}

' $t$ ' value of Mental Health among Patients of Cancer follows as shown below.

Table No - 1, 't' value of Mental Health for Positive Self Evaluation between Male and Female Patients of Cancer

\begin{tabular}{|c|c|c|c|c|c|c|}
\hline Group & $\mathrm{N}$ & $\mathrm{M}$ & $\mathrm{SD}$ & $\mathrm{df}$ & 't' value & $\begin{array}{c}\text { Level of } \\
\text { Significant }\end{array}$ \\
\hline Male & 30 & 24.27 & 3.10 & \multirow{2}{*}{58} & 0.17 & N.S. \\
\hline Female & 30 & 24.40 & 2.96 & &
\end{tabular}

N.S. = Not Significant

Table No - 2, 't' value of Mental Health for Perception of Reality between Male and Female Patients of Cancer

\begin{tabular}{|c|c|c|c|c|c|c|}
\hline Group & $\mathrm{N}$ & $\mathrm{M}$ & $\mathrm{SD}$ & $\mathrm{df}$ & 't' value & $\begin{array}{c}\text { Level of } \\
\text { Significant }\end{array}$ \\
\hline Male & 30 & 20.40 & 2.33 & 58 & 1.34 & N.S. \\
\hline Female & 30 & 21.27 & 2.69 & 58 & \\
\hline
\end{tabular}

N.S. = Not Significant 
Table No - 3, 't' value of Mental Health for Integration of Personality between Male and Female Patients of Cancer

\begin{tabular}{|c|c|c|c|c|c|c|}
\hline Group & $\mathrm{N}$ & $\mathrm{M}$ & $\mathrm{SD}$ & $\mathrm{df}$ & 't' value & $\begin{array}{c}\text { Level of } \\
\text { Significant }\end{array}$ \\
\hline Male & 30 & 28.23 & 4.88 & \multirow{2}{*}{58} & 1.74 & N.S. \\
\hline Female & 30 & 30.33 & 4.47 & &
\end{tabular}

N.S. = Not Significant

Table No-4, ' $t$ ' value of Mental Health for Autonomy between Male and Female Patients of Cancer

\begin{tabular}{|c|c|c|c|c|c|c|}
\hline Group & $\mathrm{N}$ & $\mathrm{M}$ & $\mathrm{SD}$ & $\mathrm{df}$ & 't' value & $\begin{array}{c}\text { Level of } \\
\text { Significant }\end{array}$ \\
\hline Male & 30 & 14.57 & 2.85 & 58 & 0.66 & N.S. \\
\hline Female & 30 & 15.07 & 3.07 & 58 & \\
\hline
\end{tabular}

N.S. = Not Significant

Table No - 5, ' $t$ ' value of Mental Health for Group-Oriented Attitude between Male and Female Patients of Cancer

\begin{tabular}{|c|c|c|c|c|c|c|}
\hline Group & $\mathrm{N}$ & $\mathrm{M}$ & $\mathrm{SD}$ & $\mathrm{df}$ & 't' value & $\begin{array}{c}\text { Level of } \\
\text { Significant }\end{array}$ \\
\hline Male & 30 & 24.80 & 3.03 & \multirow{2}{*}{58} & 0.76 & N.S. \\
\hline Female & 30 & 25.37 & 2.87 & \\
\hline
\end{tabular}

N.S. = Not Significant

Table No - 6, ' $t$ ' value of Mental Health for Environmental Mastery between Male and Female Patients of Cancer

\begin{tabular}{|c|c|c|c|c|c|c|}
\hline Group & $\mathrm{N}$ & $\mathrm{M}$ & $\mathrm{SD}$ & $\mathrm{df}$ & 't' value & $\begin{array}{c}\text { Level of } \\
\text { Significant }\end{array}$ \\
\hline Male & 30 & 22.83 & 3.31 & 58 & 0.20 & N.S. \\
\hline Female & 30 & 23.03 & 4.41 & 58 & \\
\hline
\end{tabular}

N.S. = Not Significant

Table No - 7, ' $t$ ' value of Overall Mental Health between Male and Female

\begin{tabular}{|c|c|c|c|c|c|c|}
\hline Group & $\mathrm{N}$ & $\mathrm{M}$ & $\mathrm{SD}$ & $\mathrm{df}$ & 't' value & $\begin{array}{c}\text { Level of } \\
\text { Significant }\end{array}$ \\
\hline Male & 30 & 135.10 & 12.81 & 58 & 1.25 & N.S. \\
\hline Female & 30 & 139.47 & 14.21 & 58 & \\
\hline
\end{tabular}

N.S. = Not Significant 


\section{DISCUSSIONS}

The chief aim of the present research was to examine Mental Health among Patients of Cancer. The derived result shows that out of seven hypotheses, while seven hypotheses have been accepted.

The difference of Positive Self-Evaluation of Mental Health between Male and Female Patients is found to be not significant. There- fore, the hypothesis is accepted. The Positive SelfEvaluation is a Part of daily life; i.e. there is no difference in Positive Self-Evolution between Male and Female Patients. The Constructive Self-Evaluation is individual's own accomplishment. This is an individual matter. Each individual must Self-Evaluate personally for himself. The said Self- Evaluation constructions are separate for male and female but there is no difference in it.

The difference of Perception of Reality of Mental Health between Male and Female Patients is found to be not significant. There fore, the hypothesis is accepted. There is no difference in perception of reality between male and female patients. Perhaps, because an individual becomes realistic for resolution of his issues. An individual thinks about true-false and loss or benefit in each situation. Simultaneously, he tries to find solution of hiss issues by making realistic evaluation of his capability to work by making his aim efforts clear and fixed. (Patel M. 1989).

The difference of Integration of Personality of Mental Health between Male and Female Patients

is found to be not significant. There- fore, the hypothesis is accepted. There is no difference in Integration of Personality between Male and Female Patients. The reason is that personality is dynamic. The Personality is revolutionary. When an individual meet fatal illness, physical and behavioural changes take place in him. That too, when there is illness like Cancer, the effect of such change take place on his personality. (Vohra A. 1999)

The difference of Autonomy of Mental Health between Male and Female Patients is found to be not significant, which hypothesis is accepted, there is no difference in Autonomy between Male and Female Patients. Perhaps, the patient being an adult morally, he can become proper guide to himself. Further, there is no difference in autonomy of male and female patient. The reason may also be that the patient possesses strength to behave with proper special reaction in view of external elements working in his position. (Mathur S. S. 1985)

The difference of Group-Oriented Attitude of Mental Health between Male and Female Patients is found to be not significant, which hypothesis is accepted. There is no difference in GroupOriented Attitude between Male and Female Patients. The constructive attitude group is the best characteristic of mental health. Here, there is no difference in attitude of both patients. Perhaps, there may be a reason behind it that the body, which was working with sufficient quantum earlier, is not working during the illness. Many times, support of others is required to be taken, for which positive attitude towards others also requires to be maintained. (Vicki S. 1996) 
The difference of Environmental Mastery of Mental Health between Male and Female Patients is found to be not significant, which hypothesis is accepted. There is no difference in Environmental Mastery between Male and Female Patients. Perhaps, the patient may have idea that when an illness like Cancer has caught, the atmosphere will also have to be understood and will also have to be organized, let the said atmosphere may be family, professional, social or friend group. The social philosophy of life; i.e. social feeling, feeling of love is also very important matter. (Garrett. 1968)

The difference between overall Mental Health of Male and Female patients is found to be not significant, which hypothesis is accepted. Meaning there by that there is no difference in overall Mental Health between Male and Female Patients. The mental health is not a state of an individual. It is an aim to be attained by individual. The said aim is not attained easily and successfully. Once the said aim is attained, it is also not that the said state will maintain permanently. In dynamic world, an individual should make continuous active efforts to attain organization in his Environment.

\section{CONCLUSIONS}

1) The difference in Positive Self Evaluation between Male and Female Patients of Cancer was Not Significant.

2) The difference in Perception of Reality between Male and Female Patients of Cancer was Not Significant.

3) The difference in Integration of Personality between Male and Female Patients of Cancer was Not Significant.

4) The difference in Autonomy between Male and Female Patients of Cancer was Not Significant.

5) The difference in Group-Oriented Attitude between Male and Female Patients of Cancer was Not Significant.

6) The difference in Environmental Mastery between Male and Female Patients of Cancer was Not Significant.

7) The difference in Overall Mental Health between Male and Female Patients of Cancer was Not Significant.

\section{REFERENCES}

(1) Contractar, B.M. (1998). $1^{\text {st }}$ Ed, 'Experimental Psychology theory \& Statistics', Viral Publishing, Ahemdabad, p.21. 
(2) Coyne, J.C. (2010). 'Positive Psychology in Cancer Care: Bad Science, Exaggerated Claims and Unproven Medicine', University of Pennsylvania School of Medicine, Publish online.

(3) Garrett, H.E. (1968). $2^{\text {nd }}$ Ed, 'General Psychology', Eurasia Publishing House, New Delhi, p.505.

(4) Kothari, S.S. (2000). 'A Study of Mental Health among Patients of T. B.', $17^{\text {th }}$ Annual Conference Gujarat Psychology Association, Junagadh, p.33.

(5) Mathur, S.S. (2005). $2^{\text {nd }}$ Ed, 'Health Psychology', Vinod Pustak Mandir, Agra, pp.46-61.

(6) Mathur, S.S. (1985). $1^{\text {st }}$ Ed, 'Clinical Psychology', Vinod Pustak Mandir, Agra-2, p.256,497.

(7) Parekh, S.C. and Dixit, H. K. (1995). $1^{\text {st }}$ Ed, 'A Statistical Testing In Psychological Researches', Chanmpa Publishing, Junagadh, p.505.

(8) Patel, M. (1989). $3^{\text {rd }}$ Ed 'Abnormal Psychology', University Book Production, Ahemdabad, p.324,558.

(9) Patel, S. (2004). $3^{\text {rd }}$ Ed 'Aarogy ni Aaspas', Indian Medical Association Morbi, pp,1-7.

(10) Schreiberm, J. (1951). 'Mental Health Flowers in Democratic Social', Mental Health Bulletin, Jillions Society for Mental Hygiene, pp.1-3.

(11) Shreevastav, A.K. and Jagdish, (1982). 'Mental Health Inventory', Agra, pp.1-9.

(12) Thummar, B.K. (2009). 'An Analytical Study of death Anxiety and Mental Health among AIDS Patients', M. K. Bhavnagar University, Bhavnagar, pp.258-266.

(13) Vicki, S. and Sheldon, C. (1996). 'Social Support and Adjustment To Cancer: Reconciling Descriptive, Co relational And Intervention Research', Health Psychology, Vol.-15 No-2, pp.135-148.

(14) Vohra, A. (1999). $1^{\text {st }}$ Ed, 'Manisik Saasthy aur Manahchikitsa', Arya Publishing, Delhi, p. 19 . 